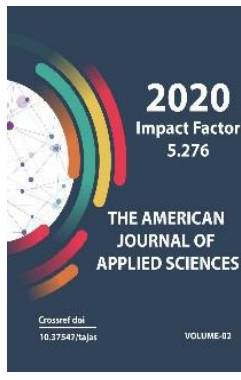

Journal Website: http://usajournalshub.c om/index,php/tajas

Copyright: Original content from this work may be used under the terms of the creative commons attributes 4.0 licence.

\section{Ways To Develop Ecotourism In The Molguzar Mountains}

\author{
Gudalov Mirkomil \\ And Fundamentals Of Economics, Uzbekistan \\ Janizokova Gulshoda \\ 2nd Year Master's Degree Student In Geography At JSPI, Uzbekistan \\ Janizokov llyos \\ 2nd Year Master's Degree Student In Geography At JSPI, Uzbekistan
}

Assosciate Professor, Candidate Of Geographical Science, JDPI Department Of Geography

\title{
ABSTRACT
}

A comprehensive study of the natural objects and natural monuments of Mount Molguzar provides scientific advice and feedback for development in ecotourism.

\section{KEYWORDS}

Molguzar Mountain, ecotourism, tourists, recreational resources, tourist route, natural monuments, natural objects, eco-village.

\section{INTRODUCTION}

In the north-west of the Turkestan ridge, the Molguzar Mountains are separated, $75 \mathrm{~km}$ long from the Goralash Pass to the Amir Temur Gate (Ilonutdi Gorge) and 10-15 km wide. The cross-sectional shape of Mount Molguzar is asymmetrical. Mount Molguzar is the northern watershed of the Sangzor River Basin, descending from east to west (900 m).
The northern slope of Mount Molguzar is flat and long. It was carved and fragmented by several streams (Achchisoy, Karamazor, Toylonsoy, Archansoy, Jontutsoy, Pishagorsay, Uobsoy, Korpasay, Rovotsay and Saykhonsay). The density of vegetation decreases from east to west. The highest point is the Shorbel Pass $(2621 \mathrm{~m})$ almost to the center of the ridge [1. Alibekov L]. 
To the north of the Shorbel Pass, in a single meridional line, is the Pishagor Cave. Pishagor Cave is located on the right side of Dolankuduksay, a tributary of Pishagor, $20 \mathrm{~km}$ south of the village of Pishagor on the JizzakhZaamin highway. The most interesting aspect here is that the names of the village, cave, and river are called by a single common name, that is the name of Pishagor.

On the Jizzakh-Zaamin highway, the Khojai Sarob ota shrine is $20 \mathrm{~km}$ south of the road sign. This is $20 \mathrm{~km}$ distance, we can get the distance $15 \mathrm{~km}$ by car, $5 \mathrm{~km}$ by horse or on foot. The last $5 \mathrm{~km}$ of road leads to the ravines and trails of Mount Molguzar. Along the way we can see the shrine and spring of "Khojai Sarob ota". The locals call this step "Khojai Sarob ota shrine" (the owner of the water head). Due to the fact that there is a spring in the area of the shrine, it differs from the surrounding areas by its nature. At the top there is the mausoleum "Khojai Sarob ota". In front of the mausoleum there is a mosque, which gives a special glory to the nature of the shrine. The great scholar Mawlana Muhammad Peshagari (born in 1321, year of death unknown) is buried here. Fakhriddin Ali ibn Waiz al-Kashifi's book Rashkhatu aynul hayat gives some information about his scientific activity. According to these sources, Mawlana Muhammad was one of the leading representatives of the Naqshbandi sect of the Khojagon dynasty and had a high scientific potential. He was born in $700 \mathrm{AH}$, nicknamed "Khojai Serob" or "Khojai Sarob". It is said that Mawlana Muhammad Peshagari came to the foothills of Molguzar. As he passed Mount Molguzar, his eyes fell on a beautiful place of nature and he wanted to stay in this place. With this desire he built a hut and began to live there, and chose the nickname "Peshogary", which means " from Pishagar" [2. Gudalov M].

Legends about the healing properties of the spring here are still popular among the people, and whoever drinks water from it with good intentions, will be cured of his ailments, and will achieve his goal. More than 5,000 residents of Pishagor and Kangli villages drink water from the spring. The area of the Khujai Sarob ota shrine is 2.0 hectares, and in 19972001 it was reconstructed and beautified at the initiative of the local population.

Pishagor cave is located $5 \mathrm{~km}$ south of the shrine "Khojai Sarob ota", in the gorge of Mount Molguzar. Since it is a bit difficult to get to the cave by car, you have to go on foot and on horseback or by motorcycle.

In front of the Pishagor cave, large piles of stones have accumulated. The entrance to the cave is narrow, making it a little difficult for the fat man to move along the corridor. Upon entering the cave, there are three halls with a width of approximately $6-8 \mathrm{~m}$, a height of 8-10 $\mathrm{m}$ and a total length of $200 \mathrm{~m}$. In some parts of the cave, as a result of water dripping from above, small ponds and distinctive landforms were formed (Aga Burgutli, 1992). Surprisingly, such a large Pishagor cave has been studied to this day only by local geographer Sattor Karabaev (Aga Burgutli).

Khujai Sarob Ota (father) lived in this place until the end of his father's life, engaged in gardening and viticulture, and worked honestly. At the same time, they taught science to the children of the local population. It is worth noting that even today the local population is very interested in horticulture and viticulture, as well as education.

In the future, the Department of Tourism of Jizzakh region should invite cave and karst scientists to conduct large-scale research in the Pishagor cave and create all conditions for them. Then, according to the scientific conclusions of the experts, it would be expedient to equip the cave for tourist purposes and create all the amenities for visitors. 
Along with a comprehensive study of the cave, the development and implementation of the program "Cave Travel" for those interested in underground travel can attract a large influx of local and foreign tourists. This, in turn, will create employment opportunities for a certain segment of the local population by providing services to tourists.

To the west of Pishagor Cave, Rovotsay and its tributaries are located in the present day, Uobsoy and Kurpasay valleys. Due to the uniqueness of the nature of these river valleys, several children's camps (Pakhtakor, Boston, Bobur, etc.) and recreation areas have been built. Hundreds of recipients visit the area in the spring. About $90 \%$ of visitors are transferred to the population of Jizzakh cities. The main reason for this is the proximity to the city of Jizzakh $(25 \mathrm{~km})$ and regular traffic.

There are also the Three Maidens stone pillars at the confluence of the Uobsoy and the Kurpasay, and the Parpi ota and Kirkchilton shrines in the upper reaches of the Kurpasay. According to the Jizzakh Regional Tourism Committee, there is a non-terrestrial rock in the village of Uob, which locals call a "glass stone" because of its sunlight.

The Parpi ota shrine is located about $45 \mathrm{~km}$ from Jizzakh, in the village of Yalpakbash on the northern slopes of Mount Molguzar, and is revered by locals as a sacred place. The tomb of Parpi ota is very ancient, from which fragments of pottery from the II-III centuries BC were found. "Parpi ota" means "white father", and in Arabic "parfi" means "white". The name "Parpi ota" can be given to us as "father in white clothes", "father of white stone" or "father of white stone".

There is also a "Mysterious Stone" on the territory of the shrine, where the locals come to ask for forgiveness of sins, as well as the state, health and children. Those who come to visit to ask for a child, according to tradition, take a piece of stone from the "Mysterious
Stone" and have to bring it back again after having a child.

From a scientific point of view, these situations can be considered obsolete, but we believe that the local people for hundreds of years have also had an influence on the "Mysterious Stone" as a divine force and spirituality. There is an opinion that many sinners cannot pass through the "mysterious hole". In this case, the hole may not be able to pass through the stone as a result of the inability of many sinful people's spiritual experiences and thoughts to harmonize with the movement of the body.

This is a very controversial topic. We are not here to argue about whether or not The Mysterious Stone is mysterious. We would like to draw your attention to the fact that this stone, which has a geomorphological natural monument, has been preserved by the locals for several hundred years.

To the east of Mount Molguzar there are many with micro geomorphological relief features. In particular, there are geomorphological natural monuments such as "Forty Girls", "Stone Column". The difference between these geomorphological natural monuments and "Mysterious Stone" is that they are not described as divine, sacred. As a result, geomorphological natural monuments have become in need of protection due to the extensive damage caused by the local population. The main feature of the "Mysterious Stone", which is a geomorphological natural monument, is preserved to this day without damage, and the locals glorify the stone as a "sacred mysterious hole". Today, the Parpi ota shrine and the Mysterious Stone Stone remain one of the most visited shrines by locals.

Above these places, on the slopes of Mount Molguzar, there is a small village called Altiovuz, which has a charming nature. The village was named Oltiovuz because it was 
built at the confluence of six rivers. In this village on the slopes of Molguzar, electricity can be obtained from micro-hydropower plants built on river water, the surrounding area is covered with walnut trees (some walnuts are 800 years old) and the forest area is also large. Most importantly, its nature has been preserved in its purest form.

In the future, to turn the pure mountain village of Oltiovuz into an "eco-village", to build seasonal grass or cotton houses along the river, to get electricity from microhydropower plants built entirely in the rivers, to prevent cars from entering the countryside, and to provide food for local farmers. products should be prepared at the expense of. Tired of the hectic city life, tourists can quickly become fascinated by the natural lifestyle in the 'eco-village'. Most importantly, when relaxing in the bosom of nature, it is easy to attract European tourists, who prioritize environmental requirements.

Walking west from the village of Altiovuz, that is, on the westernmost wing of Mount Molguzar, we can see the Saykhansay inscriptions and the Saykhansay gorge of the same name. The Saykhansay inscriptions consist of petroglyphs carved into the rocks of Mount Molguzar in BC, some of which have survived to the present day. Most of the paintings were covered by sand particles brought by the wind [3. Sharipov Sh].

In the future, if the paintings in Saykhansay are fully studied by experts, they can become as valuable as the ancient unique paintings on the rocks of the Sarmishsay valley in the southern slope of Mount Nurata, attracting many tourists [4. Sharipov Sh].

In the westernmost part of Mount Molguzar, in the Ilonutdi gorge, the Sangzor River descends into rocky, bare, steep slopes. The average relative height of this mountain, which is made of steep bare rocky mountains, is 50 meters, some 100 meters and higher. This rocky mountain has the potential to develop an extreme mountaineering sport like the European Alps. True, there are no opportunities to conquer high peaks here, but there are great opportunities to prepare amateur climbers to conquer large peaks by conquering small peaks.

\section{RESULT}

As a result of studying the evolution of Mount Molguzar as a natural object and natural monuments from east to west, we make the following suggestions and comments:

- A new approach to the development of international mountain tourism, ie the scientific study of the vertical transformation of tourist facilities from the plains to the mountains;

- increase the number of guides and volunteers in the region, serving international tourists, fluent in English and other foreign languages;

- For the first time a comprehensive study and analysis of tourist facilities on Mount Molguzar;

- Study and tourist assessment of natural objects in the Molguzar mountain, such as waterfalls, streams, springs, streams, caves, natural stone columns, ravines, several hundred-year-old spruce and walnut;

\section{REFERENCES}

1. Alibekov L, Alibekova S, Hazarov I, Gudalov M. About some regularities of degradation geosystems in Central Asia. Tatranka Javorina, Slovakia, 2012, Vol 21, № $-1,42-44 \mathrm{r}$

2. Gudalov M. Foundation of Aydar-Arnasay lakes system and their effects on the environmental landscape. Nature and Science.Volume 17, Number 11 November 25, 2019 USA New York.

3. Sharipov Sh, Gudalov M, Shomurodova Sh. Geolologic situation in the AydarArnasay colony and its atropny. Journal of 
Critical Reviews. Volume 7, Issue 3, 2020 Malaysia Kuala Lumpur.

4. Sharipov Sh, Shomurodova Sh, Gudalov $M$. The use of the mountain kars in the tourism sphere in cort and recreation zone of Chimgan-Charvak. Journal of Critical Reviews. Volume 7, Issue 3, 2020 Malaysia Kuala Lumpur.

5. Gudalov Mirkomil, Gozieva Matluba WAYS TO DEVELOP MODERN ECOTOURISM IN THE ZAAMIN BASIN.

6. Gudalov Mirkomil, Zikirov Bakhtiyor, Imamova Dilfuza Predicting Changes In Landscapes Around The AydarArnasay Lake System. The American Journal of Engineering and Technology. : https://doi.org/10.37547/tajet/Volume02ls sue10-02

7. Gudalov Mirkomil, Zikirov Bakhtiyor METHODS OF STUDYING THE LANDSCAPES AROUND THE AYDARARNASAY LAKE SYSTEM. https://doi.org/10.17605/OSF.IO/E7NVR 